\title{
Influence of Psychological Climate on Organization Performance at Kakamega County Government, Kenya
}

\author{
Robert M Nzuki ${ }^{1 \#}$, Appolonius Shitiabai Kembu ${ }^{2}$ \\ ${ }^{1}$ Masters of Arts in Public Administration and Management, School of Business and Economics, \\ Mount Kenya University, Kenya. \\ ${ }^{2}$ Lecturer, School of Business and Economics, Mount Kenya University, Kenya. \\ \#corresponding author. \\ Type of Work: Peer Reviewed. \\ DOl: http://dx.doi.org/10.21013/jmss.v16.n3.p2

\section{How to cite this paper:} \\ Nzuki, R.M., Kembu, A.S. (2020). Influence of Psychological Climate on Organization Performance \\ at Kakamega County Government, Kenya. IRA-International Journal of Management \& Social \\ Sciences (ISSN 2455-2267), 16(3), 79-87. doi:http://dx.doi.org/10.21013/jmss.v16.n3.p2
}

(c) Institute of Research Advances.

\section{(cc) BY-NC}

This work is licensed under a Creative Commons Attribution-Non Commercial 4.0 International License subject to a proper citation to the publication source of the work.

Disclaimer: The scholarly papers as reviewed and published by the Institute of Research Advances (IRA) are the views and opinions of their respective authors and are not the views or opinions of the IRA. The IRA disclaims of any harm or loss caused due to the published content to any party.

Institute of Research Advances is an institutional publisher member of Publishers International Linking Association Inc. (PILA-CrossRef), USA. The institute is an institutional signatory to the Budapest Open Access Initiative, Hungary advocating the open-access of scientific and scholarly knowledge. The Institute is a registered content provider under Open Access Initiative Protocol for Metadata Harvesting (OAI-PMH).

The journal is indexed \& included in WorldCat Discovery Service (USA), CrossRef Metadata Search (USA), WorldCat (USA), OCLC (USA), Open J-Gate (India), EZB (Germany) Scilit (Switzerland), Airiti (China), Bielefeld Academic Search Engine (BASE) of Bielefeld University, Germany, PKP Index of Simon Fraser University, Canada. 
IRA-International Journal of Management \& Social Sciences

\section{ABSTRACT}

With the approach of managing performance, employee responsibility has risen as a current authoritative idea as of late. The general objective was to establish the influence of Psychological Climate on organization performance at Kakamega County Government. The study was anchored in the Resource-Based View (RBV). The study hypothesized that there is a relationship between Psychological Climate and organization performance. The descriptive research design was applied. The target population was 332 employees of all degrees of the board and supervisory unit. Purposive examining was utilized to concentrate on specific qualities of a populace that are of enthusiasm under examination. A pilot test was directed on 10 employees to gauge the unwavering quality of the instruments. Data was examined utilizing Statistical Package for Social Sciences (SPSS) programming. To test unwavering quality and legitimacy, a pilot study was directed and Cronbach's coefficient alpha was utilized to set up consistency. A relapse model was utilized to show the connection between factors. The after-effects of the exploration were introduced utilizing recurrence, figures and diagrams. The findings of the study, there is a positive relationship between Psychological Climate and organization performance. In Conclusion, that high-quality Psychological Climate will enhance teamwork and better employee engagement to improve on overall organization performance. Study recommendation is that Kakamega County can enhance its organization performance by creating a better psychological climate. This can be done by creating an environment where there is teamwork cooperation, flexibility in schedules.

Keywords: Psychological climate, engagement, employee commitment

\section{INTRODUCTION}

The psychological climate has a big influence for organization performance, as strong support was found for psychological climate associated with the quality of employee performance (Schneider 2011), While a supportive climate fosters knowledge creation and sharing (Durcikova 2011). This, tied with the positive results within the organizational behaviour literature (James 2008 and Schneider 2011) offers compelling evidence of the importance of psychological climate for organization performance. They define this as "a knowledge worker's cognitive representations of the knowledge-sharing environment within the work unit" using three items: Information about my job performance is easily accessible, management shares performance information as it relates to my job, and to exploit information about my job performance to higher manage my work.

According to the American Psychological Association (2012), creativity together with cognitive ability, leadership, integrity, attendance and cooperation, are the factors which predict job performance. In truth, it appears naturally persuasive that individuals are more likely to interact in exceeding activities that transcend the decision of their formal duties in a favourable climate. According to Wood, Linley, Maltby, Kashdan and Hurling (2011) argue that a strengths-based psychological climate is an important situational factor that enhances employee experiences of positive affect during working hours. They conducted a three-wave longitudinal study and found that the use of strengths is significantly related to gains in positive affect after three and six months. Similarly, participation in an intervention aimed toward identifying strengths and using them during a novel way was found to guide to increased happiness as assessed over six months.

In the present corporate world, labourers' desires go past least remuneration and have changed the consideration of managers to perceiving the genuine idea of employee duty rehearses. Employee investment and employeeauthoritative commitments are vital hierarchical needs as organizations face rivalry, rivals and imaginative people, and others, particularly arising out of a worldwide downturn to accomplish. (Baley et al., 2016; Aniha, 2014).

Engagement and work fulfilment are known to be synonymous ideas; be that as it may, it can't for a fulfilled employee to fundamentally be a decent employee. (Musgrove et al., 2014). Numerous researchers in their investigations insist on the connection between hierarchical achievement and employee commitment; for instance, Albdour and Altarawneh (2014). It is significant for arrangement creators and expository and useful specialists to concentrate on the proof base to make important enhancements in employee Commitment practice, work fulfilment and hierarchical productivity. 
IRA-International Journal of Management \& Social Sciences

\section{PROBLEM STATEMENT}

With the increase in demand for quality and timely services, increase in population and scarce resources counties have been forced to recruit the best and meet their obligations to the people they serve, which led to the Emergence of devolved Governments in Kenya which has experienced dramatic changes with major functions being decentralized. Employee responsibility is one of the present issues in human asset the executives that numerous associations are confronting. Thus, employees realize that chiefs are liable for assessing their performance and see administrator support as a sign of authoritative help (Rhoades and Eisenberger, 2002). Employees see their bosses as specialists chipping away at the sake of the organization. (Baran et al., 2012).

Despite counties being the second largest employer in the country, the counties have to justify the numbers through better service delivery and customer satisfaction. According to performance management framework for county governments (2017), The counties have also been rocked with a series of employment of unqualified supervisory staff, promotion based on cronyism, in addition, they are yet to determine the influence of worker engagement in the context of supervisory support in their organizations. Research gap is seen from the research of Seniati (2010) which revealed that from research related to commitment research, still less examined the influence of psychological climate on employee performance. The psychological climate provides an indirect influence through job satisfaction. That is, job satisfaction acts as a mediator role between the psychological climate and organizational commitment. Another study conducted by Gim, Desa, and Ramayah (2015) suggests that a competitive psychological climate is negatively related to an active commitment but positively related to turnover intention. The investigation subsequently planned for crossing over the current information holes in Psychological climate on optimizing organization Performance at Kakamega county government.

\section{The objective of the Study}

This study sought to analyse the influence of Psychological Climate on organization performance at Kakamega County Government.

\section{Value of the Research}

The current study intended to provide insights into knowledge about firm Psychological Climate on organization performance. The study will contribute towards filling the gap in the body of knowledge in the practices and operations of county governments in Kenya. The study intends to establish a link between Psychological Climate on organization performance, namely, work flexibility and teamwork. This should not only ensure that the public who put their hope on county Governments for service delivery continue to reap the benefits.

\section{Literature Review}

\section{Theoretical Foundation of the research}

The RBV school of thought explains the importance of unique resources owned by an organization in achieving competitive advantage (Baumol, Litan \& Schramm, 2012). These resources take different forms including total assets expressed in monetary terms, the experience of key human resources and the overall personnel adequacy. Other measures include networks among other variables (Bhide, 2013).

\section{Empirical Literature Review}

Different components of positive working environment atmospheres that are sincerely satisfying and steady, consideration of strong group, job clearness, space for self-articulation, give suitable degrees of occupation challenge and capacity to add to authoritative achievement.

(Wollard and Shuck, 2011). Collect and Hunter (2012) found that the mental atmosphere is related emphatically to employees' work perspectives and their consequent conduct in associations. Biswas and Varma (2007) likewise saw that employees' atmosphere discernments have a noteworthy effect upon employees' citizenship practices and occupation fulfilment and in this manner emphatically sway their activity performances. Shockingly, singular 
mentalities and other brief sweeping statements of employee feelings, (for example, hierarchical duty and occupation fulfilment) have as of late been censured for not giving a comprehensive perspective on a person's self which incorporates asynchronous initiation of individual energies grinding away (Alfes et al.,2012). Devotion elucidates the enthusiastic system of Committed, where employees experience their work as important, critical and testing. Ingestion is the subjective part of Commitment whereby employees will, in general, be joyfully included and experience their work as engaging and something to which they can give their full focus (Bakker et al., 2011).

\section{Conceptual Frame Work}

The conceptual model figure 1 presents a schematic picture of the researchers presumed perception of the existing relationship between the variables. The model suggests a relationship between Psychological Climate as the independent variable and organization performance as the dependent variable that may be influenced by Psychological Climate.

\section{Fig 1. A Conceptual Model showing Psychological Climate and Organization Performance}

Independent

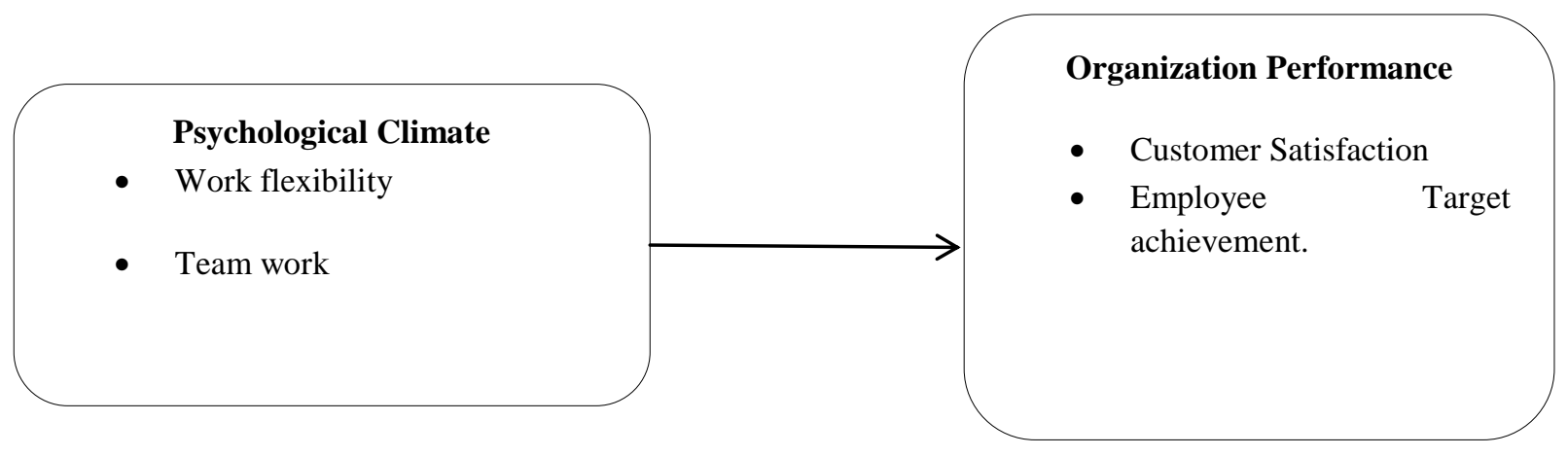

Dependent

\section{Source: Researchers (2020).}

The relationship indicated in figure 1 was envisaged to exist in organizations, but the application of different Psychological Climate tends to influence organizational performance. Psychological Climate includes work flexibility and teamwork is perceived to influence organizational performance.

\section{METHODOLOGY}

\section{Research Design}

The researcher used descriptive research design. It ensures nothing is manipulated and it describes the correlation within Variables. It provides information about real occurring situations and not experiments. As indicated by Zikmund, (2010), and expressive research configuration incorporates a procedure of gathering data which includes watching and portraying the conduct of a subject without impacting it in any capacity to address questions concerning the ebb and flow status of the subjects under examination and that it utilizes a pre-arranged structure for investigation.

\section{The population of the Study}

An examination populace is commonly an enormous assortment of people or articles that is the fundamental focal point of a logical question. Employees from Kakamega County formed the target group, management and supervisory cadre from different sub-counties 332 employees. 
IRA-International Journal of Management \& Social Sciences

\section{Sample Population}

As indicated by Mugenda and Mugenda (2003), examining implies the assortment of a given number of things from a specific populace as illustrative of that populace. Populace examining is the way toward taking a subset of subjects that is illustrative of the whole populace. Mugenda depicts $30 \%$ as a reasonable portrayal.

\section{Data Collection}

The researcher used Questionnaires which were distributed door to door with the aid of the research assistants and the respondents given a length of one week thereafter collected, compiled and analyzed the statistics. The researchers sought authority from the National Council for Science, Technology and Innovation (NACOSTI) to collect data.

\section{Test of Validity and Reliability}

Content validation was also done by dividing the instrument into several sections. Each section was checked carefully checked to ensure that it conveys the necessary message and attracts the relevant feedback, as per the tested specific themes of the research objectives and research question.

To ensure the reliability of the research instrument used in this study, a pilot study was conducted on 10 respondents who were not included in the main survey. To establish reliability results, the study tested for internal consistency using Cronbach Alpha. A threshold of 0.7 was adopted. The results indicate that Psychological Climate and organization performance had Cronbach Alpha value above 0.7 which indicates that the data was reliable. This is consistent with Cronbach (1951).

Table 1: Reliability Test Results

\begin{tabular}{|l|c|c|c|}
\hline Scale & Cronbach's Alpha & Number of Items & Comment \\
\hline Psychological Climate & 0.728 & 6 & Reliable \\
\hline Organizational Performance & 0.782 & 5 & Reliable \\
\hline
\end{tabular}

Source: Field Data (2020)

\section{Data Analysis and Interpretation}

Simple linear regression analysis was used to establish the nature and magnitude of the relationship between variables, and to test the hypothesized relationship. The coefficient $\mathbf{r}$ indicates the strength and direction of the linear relationship between the variables of the study. The relationship is strong where $\mathbf{r}=0.5$ and above, moderately strong when $\mathbf{r}$ is between 0.3 and 0.49 , weak when $\mathbf{r}$ is below 0.29 , and a correlation of 0 indicates no relationship.

\section{Response Rate}

A total of 202 questionnaires were administered to the Chief Officers, Directors, Administrators and head of departments at sub-county and ward levels in Kakamega County. Out of the number, 115 questionnaires were properly filled giving a response rate of 57\% which was satisfactory based on the argument by Kombo and Tromp (2010) which indicated that for a survey study, a response rate above $55 \%$ is satisfactory.

\section{Demographic Characteristics}

The respondent's demographic characteristics including the respondent's age, the highest level of academic qualification, working experience in the county and their category were established and presented in Table 2.

Table 2: Demographic Characteristics

\begin{tabular}{llcc}
\hline Demographic Characteristics & Category & Frequency & Percent \\
\hline & Below 25 & 20 & 17.4 \\
& $25-35$ & 32 & 27.8 \\
& $36-45$ & 39 & 33.9 \\
Age & Above 45 & 24 & 20.9 \\
Education & Masters & 23 & 20
\end{tabular}




\begin{tabular}{llll} 
& Undergraduate & 40 & 34.8 \\
& College & 52 & 45.2 \\
& Less Than 1 Year & 37 & 32.2 \\
Between 1 - 5 Years & 36 & 31.3 \\
Experience & Between 6 - 10 Years & 18 & 15.7 \\
\hline
\end{tabular}

Source: Field Data (2020)

The findings in Table 3 indicate that of the 115 respondents, 33.9\% of them were aged between 36 and 45 years, $20.9 \%$ were above 45 years of age while $45.2 \%$ were aged below 36 . On average, it can be argued that the majority of employees in Kakamega county are aged above 36 years. The results also established that majority of the respondents, $45.2 \%$, had a college level of education as their highest, $34.8 \%$ of them had an undergraduate while $20 \%$ had masters. The results imply that the majority of employees in Kakamega County in the category of Chief Officers, Directors, Administrators and head of departments at sub-county and ward levels in Kakamega County have an undergraduate degree and above.

The results also revealed that majority of the respondents, $32.2 \%$, had a work experience below a year at the time of the study, $31.3 \%$, on the other hand, had work experience between 1 and 5 years while only $36.6 \%$ of the respondents had worked for a period more than 5 years. The findings imply that majority of the employees in the top management position in Kakamega county had less than 5 years' work experience which can be attributed to changing political regimes.

\section{Descriptive Statistics}

Descriptive Findings of Psychological Climate

The respondents rated five-point Likert scale questions on Psychological Climate and the findings are indicated in Table 6.

Table 3: Descriptive Findings of Psychological Climate

\begin{tabular}{lcc} 
Statement & Mean & Standard Deviation \\
Employees in collaboration participate to take care of business & 4.18 & 0.94 \\
Opportunity to conclude how to do work & 3.17 & 1.16 \\
Have an inclination that a piece of a major family in the association & 3.97 & 1.06 \\
Adaptability in plans & 3.77 & 0.96 \\
Fulfilment with yearly paid leave & 3.68 & 1.06 \\
Fulfilment with health advantages & 3.50 & 1.13 \\
\hline Average & $\mathbf{3 . 7 1}$ & $\mathbf{1 . 0 5}$ \\
\hline
\end{tabular}

Source: Field Data (2020)

The results provided in Table 3 suggests that the respondents agreed that personnel in teamwork cooperate to get the process finished $(M=4.18)$, they feel like a part of a big family inside the organization $(M=3.97)$, there is flexibility in schedules $(M=3.77)$, they are satisfied with their annual paid leave $(M=3.68)$ as well as their medical 
benefits $(\mathrm{M}=3.50)$. The respondents, however, neither agreed nor disagreed on whether they are given the freedom to decide how to do a job $(\mathrm{M}=3.17)$.

Overall, the results imply that the psychological climate in Kakamega county is favourable $($ Average Mean $=3.71)$. A standard deviation of 1.05indicated that the responses were not varied implying that the majority agreed with the rating on psychological climate in Kakamega County.

\section{Descriptive Findings of Organization Performance}

The respondents rated five-point Likert scale questions on Organization Performance and the findings are indicated in Table 4.

Table 4: Descriptive Findings of Organization Performance

\begin{tabular}{lcc}
\hline Statement & Mean & $\begin{array}{c}\text { Standard } \\
\text { Deviation }\end{array}$ \\
\hline $\begin{array}{l}\text { Administration conveyance is according to client desire } \\
\text { Nature of administration keeps clients steadfast and thus rehashed visits } \\
\text { happen }\end{array}$ & 3.90 & 0.99 \\
Association minutely thinks about the client criticism and recommendations & 3.37 & 0.99 \\
Pledge to improve the nature of administrations routinely & 3.89 & 1.21 \\
Employees are prepared in their particular utilitarian territories & 3.73 & 1.04 \\
\hline Average & $\mathbf{3 . 7 4}$ & 1.22 \\
\hline Source: Field Data (2020) & $\mathbf{1 . 0 9}$
\end{tabular}

Source: Field Data (2020)

The respondents concurred that administration conveyance is according to client desire $(\mathrm{M}=3.90)$, nature of administration keeps clients steadfast and consequently rehashed visits occur $(\mathrm{M}=3.83)$, there is a pledge to improve the nature of administrations consistently $(\mathrm{M}=3.89)$ and that employees are prepared in their useful territories $(\mathrm{M}=3.73)$. The respondents anyway neither concurred nor differ that the association minutely thinks about the client criticism and recommendations $(\mathrm{M}=3.37)$.

Table 5: Influence of Psychological Climate on Organization Performance

Model summary

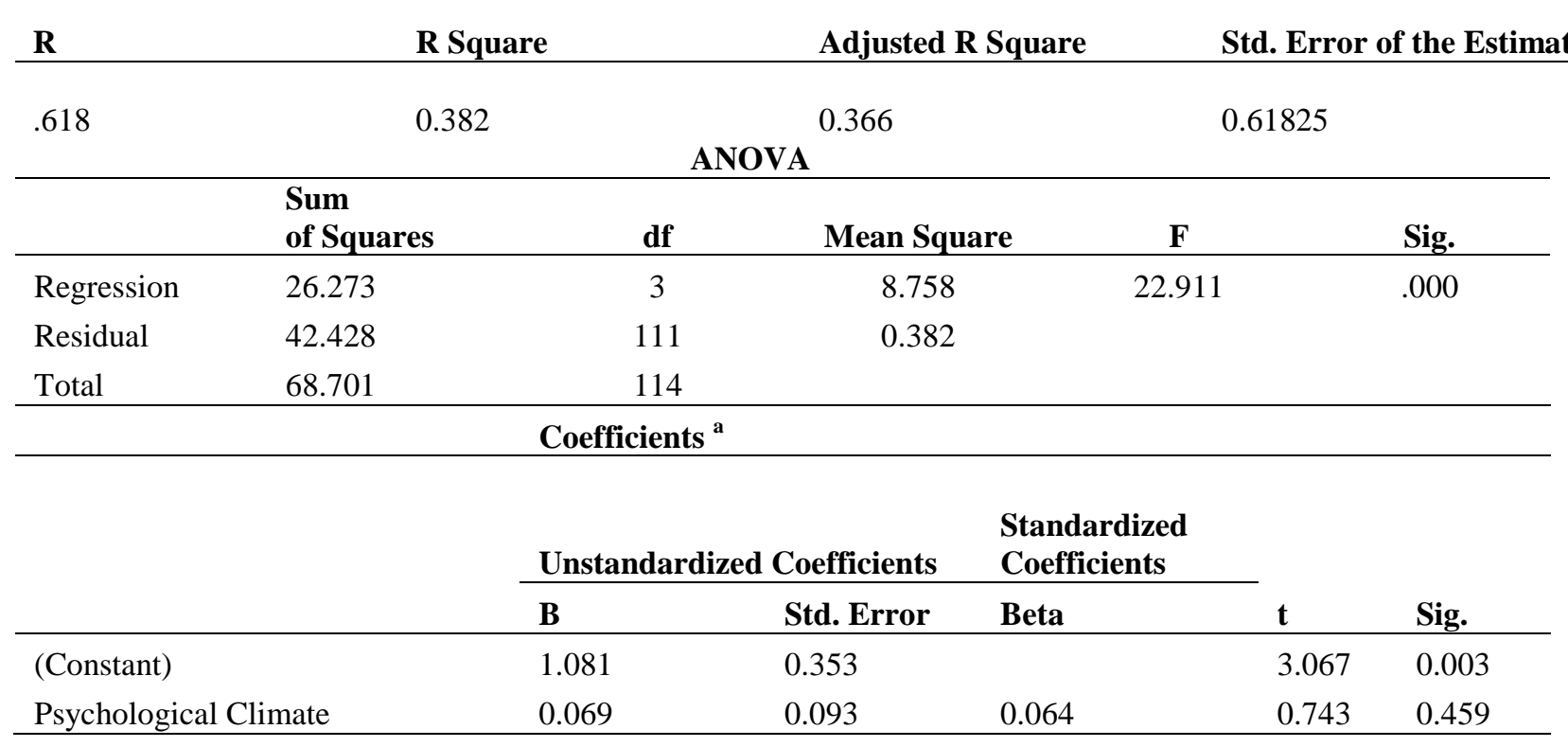


Dependent Variable: Organization Performance

Source: Field Data (2020)

a. Predictors: (Constant), Psychological Climate

b. Dependent Variable: Organization Performance

The model summary results in Table 5 indicate that the $\mathrm{F}$ statistic value of 22.911 is significant $(\mathrm{P}$-value $<0.05)$. This implies that the regression model linking Psychological Climate, to organization performance was fit and can predict the outcome.

As indicated in Table 5, holding other factors constant that is Psychological Climate, organization performance is 1.081 which is positive.

It was also established that psychological climate has a positive but not significant effect on organization performance $(\beta=0.069$; P-value $>0.05)$. This implies that a unit increase in psychological climate leads to an insignificant increase in organization performance by 0.069 units. The findings are consistent with (Schneider 2011), who established that Psychological Climate predicts a positive effect of work outcomes.

\section{CONCLUSION AND RECOMMENDATIONS}

\section{Conclusion}

It was concluded that a better psychological climate where there is teamwork cooperation, flexibility in schedules; satisfactory annual paid leave and medical benefits improve organizational performance but not significantly.

\section{Recommendation}

The study recommends that Kakamega County can enhance its organization performance by creating a better psychological climate. This can be done by creating an environment where there is teamwork cooperation, flexible work schedules; satisfactory annual paid leave and medical benefits.

\section{ACKNOWLEDGEMENT}

The research was conducted under Research Permit NACOSTI/P/19/73254/30970 that was issued by the National Council of Science, Technology and Innovation (NACOSTI) Nairobi, Kenya.

\section{References}

[1]. Albdour, A.A. what's more, Altarawneh, I.I. (2014) Employee responsibility and authoritative duty; proof from Jordan. General Journal Of Business, 19, 192-212

[2]. Alfes, K., Shantz, A. and Truss, C. (2012). 'The link between perceived HRMpractices, performance and well-being: the moderating effect of trust in the employer'.Human Resource Management Journal,22: 4, 409-427

[3]. Bailey, A. An., Albassami, F., and Al-Meshal, S. (2016). The occupations of representative work satisfaction and various levelled obligation within exhibiting worker bank. Journal of Bank Advertising, 34(6), 821-840.

[4]. Bakker, A. B., Albrecht, S. L., \& Leiter, M. P. (2011). Key questions regarding work engagement.European Journal of Work and Organizational Psychology,20(1),4-28.

[5]. Baumol W., Litan R., and Schramm C. (2012). Extraordinary private business enterprise, awful free organization, and the economic matters of development and thriving. New safe haven, ct: Yale University Press.

[6]. Biswas Soumendu and Subir Verma (2007), Psychological climate and individual performance in India: Test of a mediated model. DOI: http://dx.doi.org/10.4135/9788132106760.n6

[7]. Bhide, A. (2013). Self-Efficacy: in reference book of human conduct. Ramachaudran, V.S VOL. 4, 71-81

[8]. Benjamin E. Baran, Linda Rhoades Shanock. Lindsay R. Miller (2012) Advancing Organizational Support Theory into the Twenty-First Century World of Work; Journal of Business and Psychology ISSN 0889-3268 J Bus Psychol DOI 10.1007/s10869-011-9236-3

[9]. Durcikova, A., Fadel, K. J., Butler, B. S., Galletta, D. F. 2011. "Knowledge Exploration And Exploitation: The Impacts Of Psychological Climate And Knowledge Management Systems," Information Systems Research(22:4), Pp. 855-866.

[10]. Kombo, \& Tromp. (2011). Proposal and Thesis Writing. Nairobi: Pauline's Publication Africa

[11]. Krishnamurti \& A.N.L. SeniatiDiversity in Unity: Perspectives from Psychology and Behavioral Sciences - Ariyanto et al. (Eds)@ 2018 Taylor \& Francis Group, London, ISBN 978-1-138-62665-2 
[12]. Musgrove, C.., Ellinger, A.., \& Ellinger, A. (2014) Examining the influence of strategic profit emphases on employee engagement and service climate. Journal of workplace learning, 26(3/4) 152-171.

[13]. Mugenda, O. M. what's more, Mugenda, A. G. (2003). Investigate procedures: quantitative and emotional methodologies. Nairobi: African place for innovation considers.

[14]. Rhoades, L., and Eisenberger, R. (2002). Seen definitive assistance: a review of the composition. Journal of Applied Brain Research, 87(4), 698-714.

[15]. Schneider K. A. (2011). Attention alters decision criteria but not appearance: A reanalysis of Anton-Erxleben, Abrams, and Carrasco (2010). Journal of Vision, 11(13):7, 1-8, http://www.journalofvision.org/content/11/13/7, DOI:10.1167/11.13.7.

[16]. Schneider, B., Ehrhart, M. G., And W.H. Macey 2011b. "Perspectives On Organizational Climate And Culture," In Handbook Of Industrial And Organizational Psychology S. Zedeck (Ed.). Washington, D.C: Psychological Association, Pp. 373-414.

[17]. Wood, A. M., Linley, P. A., Maltby, J., Kashdan, T. B., \& Hurling, R. (2011). Using personal and psychological strengths leads to increases in well-being over time: A longitudinal study and the development of the strengths use questionnaire. Personality and Individual Differences, 50, 15-19.

[18]. Wollard, K. K., \& Shuck, B. (2011). Antecedents to employee engagement: A structured review of the literature. Advances in Developing Human Resources.

[19]. Zikmund-Fisher B, Fagerlin A, Ubel P (2010): A demonstration of "less can be more" in risk graphics. Med Decis Making. 2010, 30 (6): 661-671. 10.1177/0272989X10364244. 